\title{
ANALISIS FAKTOR YANG MEMPENGARUHI HARGA DAN INTEGRASI HARGA OLEIN
}

\author{
Desak Putu Ristami Paramita ${ }^{1}$, Nunung Nuryartono ${ }^{2}$, Noer Azam Achsani ${ }^{2}$ \\ ${ }^{1}$ Mahasiswa Magister Program Studi Ilmu Ekonomi, FEM IPB \\ ${ }^{2}$ Staf Pengajar FEM IPB
}

Artikel diterima Februari 2015

Artikel disetujui untuk dipublikasikan Juli 2015

\begin{abstract}
Olein production increased by 107.5 percent from 2002 to 2013. There was a change in consumption patterns where the consumption of olein intended for export has risen from only 39 percent in 2002 to 65 percent in 2013. In the beginning of 2008, olein prices increased due to the global financial crisis. In the end of 2008, olein prices decreased but since then olein prices fluctuations until the end of 2014. Many factors affecting the price fluctuations such as macroeconomic and microeconomic variables. Commodity market participants need to take action in response to price fluctuations by participating in commodity futures trading. Olein futures trading commodity in Indonesia is not well developed. This is indicated by small volumes of the transaction of olein futures contracts in Indonesia Commodity and Derivatives Exchange (ICDX) causing market participants to not using ICDX futures prices as a reference. The participants actually use the price of the Rotterdam exchange for their transactions of buying and selling. Therefore, this study aims to analyze factors influencing olein prices and analyze olein prices integration by using Vector Error Correction Model (VECM) method. Results showed that exchange rates, interest rates, money supply, CPO prices, and Indonesia's GDP affect olein prices. In addition, there is an integration between the physical prices, futures prices, and world reference prices in the long term.
\end{abstract}

Key words : Factors Affecting Price, Olein, Price Integration, VECM

\section{PENDAHULUAN}

Indonesia sebagai negara yang memiliki kekayaan alam yang berlimpah di berbagai sektor termasuk sektor perkebunan. Menurut Kementerian Pertanian/ Kementan (2014), produksi kelapa sawit Indonesia 21.958.120 ton di tahun 2010 dan meningkat dengan pertumbuhan rata-rata per tahun sebesar 8,41 persen sehingga produksi di tahun 2014 sebesar 29.344.479 ton dan menempatkan Indonesia sebagai produsen Crude Palm Oil (CPO) terbesar di dunia.

Berdasarkan data World Bank (2014), jumlah penduduk dunia telah mencapai 7.260.652.000 jiwa sedangkan penduduk Indonesia berjumlah 254.455.000 jiwa (3,5 persen dari total penduduk dunia) dan menempati urutan keempat terbesar di dunia setelah Tiongkok (1.364.270.000 jiwa), India (1.295.292.000 jiwa), dan Amerika Serikat (318.857.000 jiwa). Rata-rata Gross Domestic Product (GDP) per kapita Indonesia sebesar US \$ 3.492 per tahun dan rata-rata GDP per kapita dunia sebesar US \$ 14.938 per tahun. Semakin meningkatnya jumlah penduduk Indonesia dan dunia dan disertai peningkatan GDP per kapita akan berdampak pada 
peningkatan konsumsi termasuk peningkatan konsumsi minyak nabati. Menurut Gabungan Pengusaha Kelapa Sawit Indonesia/ GAPKI (2014), konsumsi minyak nabati dunia dari tahun 1980-2014 meningkat 8,4 kali lipat menjadi $151,618,000,000$ ton. Peningkatan konsumsi minyak nabati tersebut berdampak pada perubahan pola konsumsi minyak nabati dunia dimana saat ini pangsa minyak sawit menduduki pangsa terbesar yaitu 41 persen dari total konsumsi minyak nabati dan mengungguli dominasi minyak kedelai dengan share dunia sebesar 32 persen, minyak bunga matahari sebesar 10 persen dan minyak rappa sebesar 17 persen. Salah satu penyebab perubahan konsumsi minyak sawit tersebut adalah perubahan konsumsi pada produk turunan minyak sawit yaitu olein.

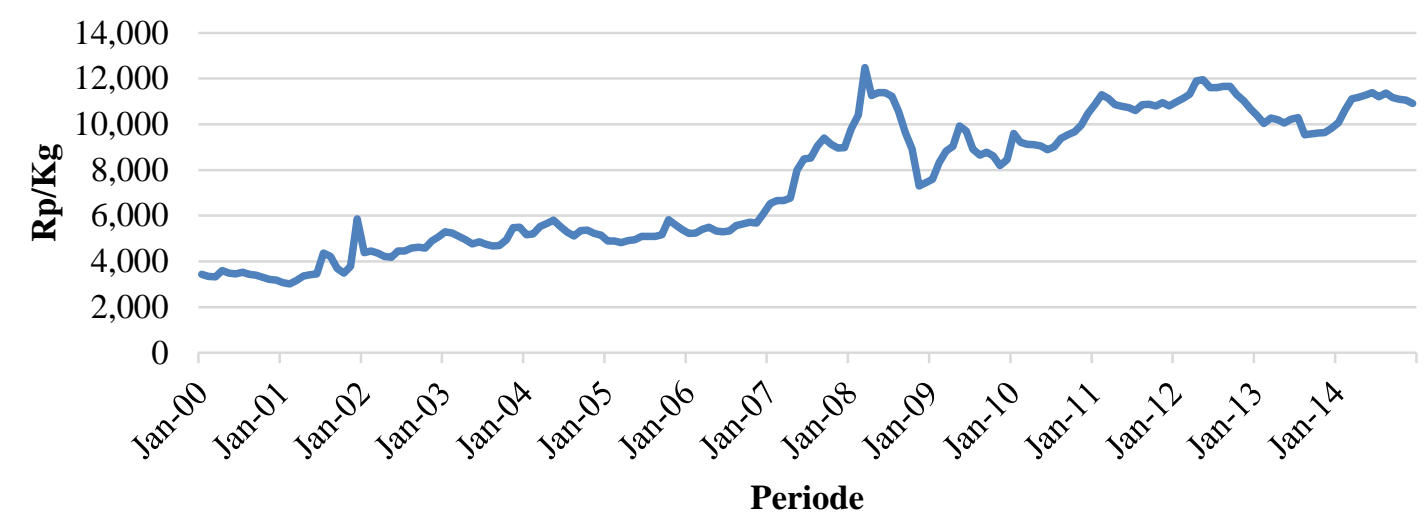

Sumber : Perdagangan Dalam Negeri (PDN), 2014

Gambar 1 Pergerakan harga olein dari Januari 2000 sampai dengan Desember 2014

\section{Refined Bleached Deodorized} Palm Olein (RBD Palm Olein) atau yang lebih dikenal minyak goreng (yang selanjutnya disebut olein) merupakan salah satu produk olahan kelapa sawit. Komoditi ini telah mengalami proses industri yaitu proses pembentukan dari buah menjadi minyak sehingga mempunyai nilai tambah. Sebagai salah satu produk turunan dari kelapa sawit, produksi olein sangat tergantung dari produksi kelapa sawit. Menurut GAPKI (2014), terjadi peningkatan produksi olein sebesar 107,5 persen dari tahun 2002 sampai dengan 2013 dan terjadi perubahan pola konsumsi dimana konsumsi olein untuk kebutuhan dalam negeri sekitar 61 persen dan konsumsi olein untuk ekspor sekitar 39 persen pada tahun 2002 sedangkan pada tahun 2013, 65 persen konsumsi ditujukan untuk ekspor dan 35 persen ditujukan untuk konsumsi dalam negeri.
Berdasarkan Gambar 1, terjadi kenaikan harga yang tajam di awal tahun 2008. Mendekati akhir tahun 2008, harga olein kembali turun tetapi sejak saat itu terjadi fluktuasi harga hingga akhir 2014. Pelaku pasar komoditi dalam negeri maupun luar negeri perlu mengambil tindakan akibat adanya fluktuasi harga komoditi. Salah satu cara yang dapat dilakukan dengan ikut serta dalam perdagangan berjangka komoditi (PBK). PBK di Indonesia sudah dilindungi oleh Undang-Undang (UU) No. 32 Tahun 1997 yang kemudian diamandemen dengan UU No. 10 Tahun 2011. PBK di Indonesia sudah ada sejak tahun 2000 dengan satu bursa yaitu Bursa Berjangka Jakarta (BBJ). Tahun 2007, ada satu bursa lagi yang ikut meramaikan industri ini yaitu Bursa Komoditi dan Derivatif Indonesia (BKDI). 
Tabel 1 Transaksi kontrak berjangka komoditi di BKDI dari 2009 sampai dengan 2014 (lot)

\begin{tabular}{lrrrrrr}
\hline Kontrak Berjangka & 2009 & 2010 & 2011 & 2012 & 2013 & 2014 \\
\hline CPOTR & - & 193563 & 771979 & 817143 & 795296 & 605279 \\
OLEINTR & - & - & 1542 & 4374 & 1963 & 588 \\
GOLDGR & 3831 & 23285 & 12873 & 6443 & 84477 & 66707 \\
GOLDID & - & - & 7063 & 4867 & 605 & 949 \\
GOLDUD & - & - & 79366 & 113904 & 48686 & 3402 \\
PAMPGRID & - & - & - & - & - & 3578 \\
PAMPKGUD & - & - & - & - & - & 1473 \\
\hline
\end{tabular}

Sumber : Badan Pengawas Perdagangan Berjangka Komoditi (Bappebti), 2014

Sebagai bursa berjangka komoditi kedua di Indonesia, BKDI telah memperdagangkan tujuh kontrak berjangka komoditi yaitu minyak sawit dengan kode kontrak CPOTR, olein dengan kode kontrak OLEINTR, emas dengan kode kontrak GOLDGR, GOLDID, GOLDUD, PAMPGRID, dan PAMPKGUD. Dari data pada Tabel 1, dapat dilihat bahwa jumlah transaksi kontrak berjangka olein di bursa ini masih kecil dibandingkan jumlah transaksi di bursa berjangka yang ada di luar negeri. Dalian Commodity Exchange (DCE) yang merupakan bursa berjangka komoditi di Tiongkok yang telah memperdagangkan kontrak berjangka olein. Tahun 2014, jumlah transaksi olein di DCE mencapai 159.992.776 lot (DCE, 2014). Masih kecilnya jumlah transaksi kontrak berjangka olein di BKDI mengakibatkan pelaku usaha komoditi belum menggunakan harga komoditi di bursa ini sebagai harga acuan.

Berdasarkan latar belakang dan perumusan masalah yang sudah dijelaskan, maka penelitian ini bertujuan untuk menganalisis faktor-faktor yang mempengaruhi harga olein serta menganalisis integrasi harga antara pasar fisik dalam negeri, pasar futures dalam negeri, dan pasar acuan dunia.

\section{METODE PENELITIAN}

Jenis data yang digunakan adalah data sekunder berbentuk time series bulanan dari Juli 2005 sampai Desember 2014 untuk analisis faktor yang mempengaruhi harga dan Desember 2011 sampai Desember 2014 untuk analisis integrasi harga. Variabel yang digunakan adalah: nilai tukar riil, suku bunga (BI Rate), jumlah uang beredar, harga minyak dunia, harga CPO dunia, GDP Indonesia, harga olein Jakarta, harga futures olein BKDI, harga olein Rotterdam, dan variabel dummy sebelum dan sesudah adanya kontrak berjangka olein di BKDI. Data tersebut diambil dari Bank Indonesia, BKDI, International Financial Statistics (IFS), Kementerian Perdagangan, dan World Bank.

Untuk menganalisis faktor yang mempengaruhi harga olein, model operasional dalam penelitian ini yaitu :

$$
\begin{aligned}
\Delta \text { OLEIN }_{t}= & a_{1}+\sum_{i=1}^{k} \alpha_{i} \Delta R E R_{t-i}+ \\
& \sum_{i=1}^{k} \beta_{i} \Delta I R_{t-i}+\sum_{i=1}^{k} \gamma_{i} \Delta M S_{t-i}+ \\
& \sum_{i=1}^{k} \delta_{i} \Delta O I L_{t-i}+ \\
& \sum_{i=1}^{k} \tau_{i} \Delta C P O_{t-i}+ \\
& \sum_{i=1}^{k} \Gamma_{i} \Delta G D P_{t-i}+\varepsilon_{t}
\end{aligned}
$$

dimana :

$\begin{array}{ll}a_{1} & =\text { konstanta } \\ \alpha, \beta, \gamma, \delta, \tau, \Gamma & =\text { parameter } \\ \varepsilon & =\text { error } \\ i, k & =\text { panjang lag } \\ \text { CPO } & =\text { harga CPO dunia } \\ \text { GDP } & =\text { GDP riil } \\ \text { IR } & =\text { suku bunga } \\ \text { MS } & =\text { jumlah uang beredar } \\ \text { OLEIN } & =\text { harga olein } \\ \text { OIL } & =\text { harga minya dunia } \\ \text { RER } & =\text { nilai tukar riil }\end{array}$


Pemilihan variabel faktor yang mempengaruhi harga didasarkan pada beberapa penelitian yaitu Balcombe (2010), Helbling et al. (2008), Arango et al. (2012), Frankel dan Rose (2010), Arshad dan Hameed (2012). Sedangkan penggunaan metode VECM dalam analisis faktor yang mempengaruhi harga berdasarkan pada penelitian Nugraheni (2014).

Model operasional yng digunakan untuk analisis integrasi harga dalam penelitian ini adalah sebagai berikut :

$$
\begin{aligned}
& \triangle O L E I N_{t}= \\
& A_{1}+\sum_{i=1}^{k} \theta_{i} \Delta \text { OLEINFUTURES } S_{t-i}+ \\
& \sum_{i=1}^{k} \vartheta_{i} \Delta \text { OLEINACUAN } \text { LI }+\epsilon_{t}
\end{aligned}
$$

dimana :

$\begin{array}{ll}A_{1} & =\text { konstanta } \\ \theta, \vartheta & =\text { parameter } \\ \epsilon & =\text { error } \\ i, k & =\text { panjang lag } \\ \text { OLEIN } & \text { harga olein di pasar } \\ & \text { fisik Indonesia } \\ \text { OLEINACUAN } & =\text { harga olein acuan } \\ \text { OLEINFUTURES }= & \text { harga olein di pasar } \\ & \text { futures BKDI }\end{array}$

Pemilihan variabel didasarkan pada penelitian Hafizah (2009). Sedangkan penggunaan metode VECM dalam analisis integrasi berdasarkan pada penelitian Nkang et al. (2007).

VECM merupakan model bentuk VAR yang terestriksi (Enders, 2004). Model ini digunakan untuk data yang nonstasioner tetapi memiliki potensi untuk terkointegrasi. Restriksi tambahan ini harus diberikan karena keberadaan bentuk data yang tidak stasioner pada level, tetapi terkointegrasi. Data time series cenderung memiliki stasioneritas pada tingkat first differences. VECM dapat memberikan informasi mengenai tingkah laku jangka pendek suatu variabel terhadap jangka panjangnya akibat adanya perubahan yang permanen. Tahapan yang dilakukan adalah uji stationeritas, uji stabilitas VAR, uji optimum lag, uji kointegrasi, impulse response function (IRF), forecast error variance decompotition (FEVD).

\section{HASIL DAN PEMBAHASAN}

\section{Analisis Faktor yang Mempengaruhi Harga Olein}

Perubahan harga olein Indonesia dapat dipengaruhi berbagai macam faktor seperti nilai tukar, suku bunga, jumlah uang beredar, harga minyak bumi, harga CPO dunia, dan GDP. Pada bagian ini, akan membahas faktor yang mempengaruhi harga olein dengan menggunakan metode VECM. Sebletum melakukan analisis VECM, perlu dilakukan pengujian-pengujian pra estimasi yaitu pengujian akar unit, pengujian stabilitas VAR dan pengujian lag optimal. Pengujian ini penting karena kebanyakan data dalam model multi variate time series mengandung akar unit sehingga akan membuat hasil estimasi menjadi semu dan tidak valid (Garigaratein di pasar Rotter 2007).

Tahap awal pengujian pra estimasi adalah pengujian akar unit. Uji ini dilakukan untuk melihat kestasioneran data time series. Data time series harus dalam kondisi stasioner yaitu tidak terdapat perubahan yang sistematis dalam mean maupun variance. Pengujian akar unit yang digunakan adalah uji Phillips Perron (PP). Uji ini dipilih karena dapat menangkap gejala structural break. Apabila hasil dari pengujian ini menunjukkan nilai mutlak adjusted t-statistik lebih besar daripada critical values maka data telah stasioner pada taraf nyata yang digunakan. Selain itu, stasioneritas dapat dilihat dari nilai probabilitasnya yaitu apabila nilai probabilitas kurang dari taraf nyata yang digunakan, maka data tersebut stasioner. 
Tabel 2 Hasil pengujian akar unit tingkat level dan first difference faktor yang mempengaruhi harga olein

\begin{tabular}{lcccc}
\hline \multirow{2}{*}{ Variabel } & \multicolumn{2}{c}{ Level } & \multicolumn{2}{c}{ First Difference } \\
\cline { 2 - 5 } & Adj t-Statistik & Probabilitas & Adj t-Statistik & Probabilitas \\
\hline LOLEIN & $-2,14$ & 0,23 & $-8,34$ & $0,0000^{*}$ \\
LRER & $-2,54$ & 0,11 & $-9,92$ & $0,0000^{*}$ \\
IR & $-1,54$ & 0,51 & $-3,73$ & $0,0048^{*}$ \\
LMS & $-0,98$ & 0,76 & $-19,22$ & $0,0000^{*}$ \\
LOIL & $-2,77$ & 0,07 & $-6,92$ & $0,0000^{*}$ \\
LCPO & $-2,32$ & 0,17 & $-6,78$ & $0,0000^{*}$ \\
LGDP & $-0,02$ & 0,95 & $-7,49$ & $0,0000^{*}$ \\
DUMMY & $-0,68$ & 0,85 & $-10,58$ & $0,0000^{*}$ \\
\hline
\end{tabular}

Keterangan : * stasioner pada taraf nyata $5 \%$

Berdasarkan uji PP yang telah dilakukan, semua variabel tidak stasioner pada tingkat level dan sudah stasioner pada tingkat first difference. Data yang tidak stasioner seringkali menunjukkan hubungan ketidakseimbangan dalam jangka pendek, tetapi ada kecenderungan terjadinya hubungan keseimbangan dalam jangka panjang. Untuk mengetahui ada tidaknya hubungan jangka panjang di dalam variabel perlu dilakukan uji kointegrasi. Oleh karena itu, untuk menganalisis informasi jangka panjang akan digunakan data level sehingga model VAR akan dikombinasikan dengan model koreksi kesalahan menjadi VECM.

Pengujian selanjutnya adalah uji stabilitas VAR. Berdasarkan uji stabilitas yang dilakukan, nilai roots of characteristic polynomial yang dihasilkan pada lag 6 kurang dari 1. Sehingga dapat dikatakan bahwa model estimasi VAR stabil pada lag 6.

Tabel 3 Hasil pengujian kointegrasi faktor yang mempengaruhi harga olein

\begin{tabular}{ccccc}
\hline Hipotesis Nol & Hipotesis Alternatif & $\begin{array}{c}\text { Trace } \\
\text { Statistic }\end{array}$ & $\begin{array}{c}\text { Critical } \\
\text { Value }\end{array}$ & Probabilitas \\
\hline $\mathrm{r}=0$ & $\mathrm{r} \leq 1$ & 180,02 & 125,61 & $0,0000^{*}$ \\
$\mathrm{r}=1$ & $\mathrm{r} \leq 2$ & 118,85 & 95,75 & $0,0005^{*}$ \\
$\mathrm{r}=2$ & $\mathrm{r} \leq 3$ & 59,31 & 69,82 & 0,2570 \\
$\mathrm{r}=3$ & $\mathrm{r} \leq 4$ & 29,58 & 47,86 & 0,7402 \\
$\mathrm{r}=4$ & $\mathrm{r} \leq 5$ & 17,60 & 29,79 & 0,5954 \\
$\mathrm{r}=5$ & $\mathrm{r} \leq 6$ & 7,73 & 15,49 & 0,4943 \\
$\mathrm{r}=6$ & $\mathrm{r} \leq 7$ & 1,31 & 3,84 & 0,2531 \\
\hline
\end{tabular}

Keterangan : * signifikan pada taraf nyata $5 \%$
Tahap pra estimasi yang selanjutnya dilakukan adalah pengujian lag optimal. Uji ini sangat penting karena lag dari variabel endogen dalam sistem persamaan akan digunakan sebagai variabel eksogen. Selain itu, uji ini bermanfaat untuk menghilangkan masalah autokorelasi dalam sistem VAR. Besarnya lag yang dipilih dalam penelitian ini adalah lag yang paling kecil, karena jika dipilih lag yang besar akan mengurangi keragaman dalam derajat bebasnya. Berdasarkan nilai SIC yang digunakan, lag 1 merupakan lag optimal.

Uji kointegrasi dilakukan untuk mengetahui apakah akan terjadi keseimbangan jangka panjang, yaitu terdapat kesamaan pergerakan dan stabilitas hubungan diantara variabel-variabel di dalam penelitian ini atau tidak. Penelitian ini menggunakan metode Johansen's Cointegration Test. 
Terdapat lima asumsi deterministic trend dalam uji kointegrasi. Pemilihan asumsi tersebut berdasarkan kriteria yang digunakan pada lag optimal. Asumsi yang digunakan adalah asumsi ketiga yaitu intercept (no trend) in $C E$ and test VAR untuk linear deterministic trend. Tahapan selanjutnya adalah menentukan jumlah kointegrasi. Ada dua kriteria yang dapat digunakan yaitu berdasarkan pada Trace Test atau Maximum eigen-value.

Berdasarkan Tabel 3 dapat dilihat bahwa nilai Trace Statistic pada $\mathrm{r}=1$ lebih besar dari critical value dengan tingkat signifikansi 5 persen. Hal ini berarti hipotesis nol yang mengatakan bahwa ada satu kointegrasi ditolak dan hipotesis alternatif yang menyatakan bahwa maksimal ada dua kointegrasi tidak dapat ditolak. Hasil analisis di atas menunjukkan bahwa diantara tujuh variabel endogen yang digunakan dalam penelitian ini terdapat dua kointegrasi pada tingkat signifikansi 5 persen.

Tahap selanjutnya adalah membentuk model VECM. Estimasi model VECM mengindikasikan hubungan keseimbangan dinamis jangka pendek dan keseimbangan jangka panjang dalam satu sistem persamaan. Dalam estimasi VECM faktor yang mempengaruhi harga olein, yang menjadi variabel dependen adalah harga olein. Nilai tukar, suku bunga, jumlah uang beredar, harga minyak dunia, harga CPO dunia, dan GDP Indonesia menjadi variabel independen. Sedangkan variabel dummy sebelum dan sesudah adanya kontrak berjangka olein di BKDI dijadikan variabel eksogen. Hasil estimasi VECM jangka pendek pada Tabel 4 menunjukkan hubungan kesamaan jangka pendek faktor-faktor yang mempengaruhi harga olein.

Tabel 4 Hasil estimasi VECM jangka pendek faktor yang mempengaruhi harga olein

\begin{tabular}{lrc}
\hline \multicolumn{1}{c}{ Variabel } & Koefisien & T-Statistik \\
\hline CointEq1 & $-0,22$ & $-5,02^{*}$ \\
D(LOLEIN (-1)) & $-0,09$ & $-1,18$ \\
D(LRER(-1)) & $-0,12$ & $-1,11$ \\
D(IR(-1)) & $-0,02$ & $-1,85$ \\
D(LMS(-1)) & 0,13 & 0,62 \\
D(LOIL(-1)) & $-0,10$ & $-2,48^{*}$ \\
D(LCPO(-1)) & 0,32 & $4,64^{*}$ \\
D(LGDP(-1)) & 1,13 & $3,23^{*}$ \\
DUMMY & $-0,01$ & $-0,91$ \\
\hline
\end{tabular}

Keterangan : * signifikan pada taraf nyata $5 \%$

Dalam jangka pendek, harga olein dipengaruhi oleh harga minyak dunia, harga CPO dunia, dan GDP Indonesia. Peningkatan satu persen harga minyak pada bulan sebelumnya akan menurunkan harga olein pada bulan ini sebesar 0,10 persen. Hasil ini didukung oleh analisis deskriptif, ketika harga minyak dunia pada Mei 2008 naik dari US \$ 112,62 per barel menjadi US \$ 125,01 per barel maka harga olein di bulan Juni 2008 menurun menjadi Rp 11.386 per kg dari Rp 11.395 per kg. Selain itu, hasil ini didukung oleh penelitian Arshad dan Hameed (2012), dimana harga minyak pada periode sebelumnya berhubungan negatif dengan harga CPO Malaysia.

Peningkatan harga CPO dunia sebesar satu persen pada bulan sebelumnya akan meningkatkan harga olein sebesar 0,32 persen pada bulan ini. Olein merupakan komoditi yang berasal 
dari CPO sehingga apabila harga CPO meningkat maka akan direspon positif dan cepat oleh harga olein. Hal ini didukung oleh penelitian Rachman (2012), dimana harga minyak goreng dipengaruhi oleh harga CPO.

Peningkatan GDP sebesar satu persen pada bulan sebelumnya akan meningkatkan harga olein sebesar 1,13 persen pada bulan ini. Hasil ini didukung oleh Frankel dan Rose (2010) dimana GDP mempengaruhi secara positif dan signifikan terhadap harga kedelai. Pada penelitian ini, adanya mekanisme penyesuaian dari jangka pendek ke jangka panjang menunjukkan adanya kointegrasi kesalahan yang signifikan dan bernilai sebesar -0,22. Jadi setiap bulan kesalahan dikoreksi sekitar 0,22 persen menuju keseimbangan jangka panjang.

Hasil estimasi jangka panjang pada Tabel 5 menunjukkan bahwa harga olein dipengaruhi oleh nilai tukar, suku bunga, jumlah uang beredar, harga CPO dunia, dan GDP Indonesia. Peningkatan satu persen nilai tukar pada bulan sebelumnya akan menurunkan harga olein sebesar 0,97 persen pada bulan ini. Hasil ini didukung oleh Bastourre et al. (2010). Peningkatan suku bunga pada bulan sebelumnya akan meningkatkan harga olein sebesar 0,05 persen pada bulan ini. Peningkatan suku bunga akan berdampak pada peningkatan biaya produksi dengan asumsi perusahaan yang memproduksi olein memanfaatkan lembaga perbankan dalam menambah modal usahanya. Peningkatan biaya produksi akan dibebankan pada harga jual produk. Sehingga adanya peningkatan suku bunga akan meningkatkan harga jual komoditi olein.

Peningkatan jumlah uang beredar pada bulan sebelumnya sebesar satu persen akan menurunkan harga olein sebesar 1,08 persen pada bulan ini. Asumsi peningkatan jumlah uang beredar akan meningkatkan investasi pada komoditi olein. Adanya peningkatan investasi berupa kemajuan teknologi dalam memproduksi olein maka akan meningkatkan supply olein di pasar. Adanya peningkatan supply olein mengakibatkan harga olein turun.

Sedangkan peningkatan satu persen harga CPO dunia pada bulan sebelumnya akan menurunkan harga olein sebesar 0,56 persen pada bulan ini. Adanya kenaikan harga CPO berdampak pada penurunan permintaan CPO. Akibatnya stok CPO di dalam negeri banyak. Asumsi produsen olein memanfaatkan kelebihan stok CPO dengan meningkatkan produksi olein. Adanya peningkatan produksi olein berdampak supply olein di pasar dalam negeri bertambah. Peningkatan supply olein akan menurunkan harga olein.

Peningkatan GDP Indonesia pada bulan sebelumnya akan meningkatkan harga olein pada bulan ini sebesar 2,19 persen. Hasil ini didukung oleh Frankel dan Rose (2010) dimana peningkatan GDP sebesar satu persen akan meningkatkan harga komoditi (kedelai) sebesar 0,05 persen.

Tabel 5 Hasil estimasi VECM jangka panjang faktor yang mempengaruhi harga olein

\begin{tabular}{ccc}
\hline Variabel & Koefisien & t-Statistik \\
\hline LRER(-1) & $-0,96$ & $-6,92^{*}$ \\
IR(-1) & 0,05 & $4,59^{*}$ \\
LMS(-1) & $-1,08$ & $-4,35^{*}$ \\
LOIL(-1) & $-0,04$ & $-0,42$ \\
LCPO(-1) & $-0,56$ & $-6,42^{*}$ \\
LGDP(-1) & 2,19 & $3,71^{*}$ \\
\hline
\end{tabular}

Keterangan : * signifikan pada taraf nyata $5 \%$ 
Setelah mengetahui faktor yang mempengaruhi harga olein, selanjutnya akan dilakukan suatu simulasi guncangan faktor dengan analisis IRF. Hasil analisis ini menggambarkan dampak saat ini dan masa depan guncangan suatu variabel terhadap variabel endogen yang lain. Respon dalam jangka pendek biasanya cukup signifikan dan cenderung berubah sedangkan respon jangka panjang cenderung konsisten. Dalam penelitian ini, akan dilihat dampak dari guncangan selama 60 periode (5 tahun). Respon guncangan faktor yang mempengaruhi harga olein dapat dilihat pada Gambar 2.

Pada bulan pertama, harga olein belum menunjukkan respon akibat adanya guncangan nilai tukar, suku bunga, jumlah uang beredar, harga minyak dunia, harga CPO dunia, dan GDP Indonesia. Guncangan dari faktor-faktor yang mempengaruhi harga olein mulai terlihat pada bulan kedua. Pada bulan kedua dan ketiga, peningkatan nilai tukar riil menyebabkan penurunan harga olein. Hasil ini didukung oleh Bastourre et al. (2010) dimana peningkatan tukar riil akan menurunkan harga komoditi dalam jangka panjang. Pada periode keempat dan selanjutnya, peningkatan nilai tukar akan meningkatkan harga olein. Hasil ini didukung oleh Harri et al. (2009) dengan menggunakan VAR yang menyatakan bahwa nilai tukar mempengaruhi secara positif harga komoditi (minyak jagung, kapas dan kedelai) dari waktu ke waktu. Guncangan nilai tukar akan stabil mulai periode ke 39 .

Guncangan suku bunga bersifat negatif terhadap harga olein dan guncangan tersebut stabil pada periode ke 33. Hal ini mengindikasikan jika terjadi peningkatan suku bunga acuan maka akan diikuti oleh kenaikan suku bunga tabungan atau deposito. Dengan adanya kenaikan suku bunga tabungan atau deposito, masyarakat akan mengalokasikan uang yang dimilikinya untuk menabung dalam bentuk tabungan atau deposito sehingga share dari pendapatan yang diterima masyarakat akan berkurang untuk konsumsi termasuk konsumsi olein. Akibat permintaan olein berkurang maka harga olein akan turun. Hasil ini didukung oleh Arango et al. (2012) dan Frankel (2006).

Guncangan jumlah uang beredar pada periode kedua sampai periode ketujuh bersifat positif. Jika terjadi peningkatan jumlah uang beredar maka harga olein akan meningkat. Menurut teori kuantitas uang, jika bank sentral mempertahankan jumlah uang beredar tetap stabil, maka harga akan stabil. Tetapi jika bank sentral meningkatkan jumlah uang beredar dengan cepat maka harga akan meningkat dengan cepat. Selain itu, adanya peningkatan jumlah uang beredar akan meningkatkan konsumsi termasuk konsumsi olein. Peningkatan permintaan olein akan meningkatkan harga olein. Hasil ini didukung oleh Ahsan et al. (2011). Mulai periode kedelapan dan seterusnya, apabila jumlah uang beredar mengalami peningkatan maka harga olein akan menurun. Asumsi peningkatan jumlah uang beredar di masyarakat akan meningkatkan investasi olein melalui peningkatan teknologi. Peningkatan teknologi dalam memproduksi olein akan meningkatkan supply olein. Dampak dari peningkatan supply olein akan menurunkan harga olein. Guncangan jumlah uang beredar akan stabil pada periode 35 . 


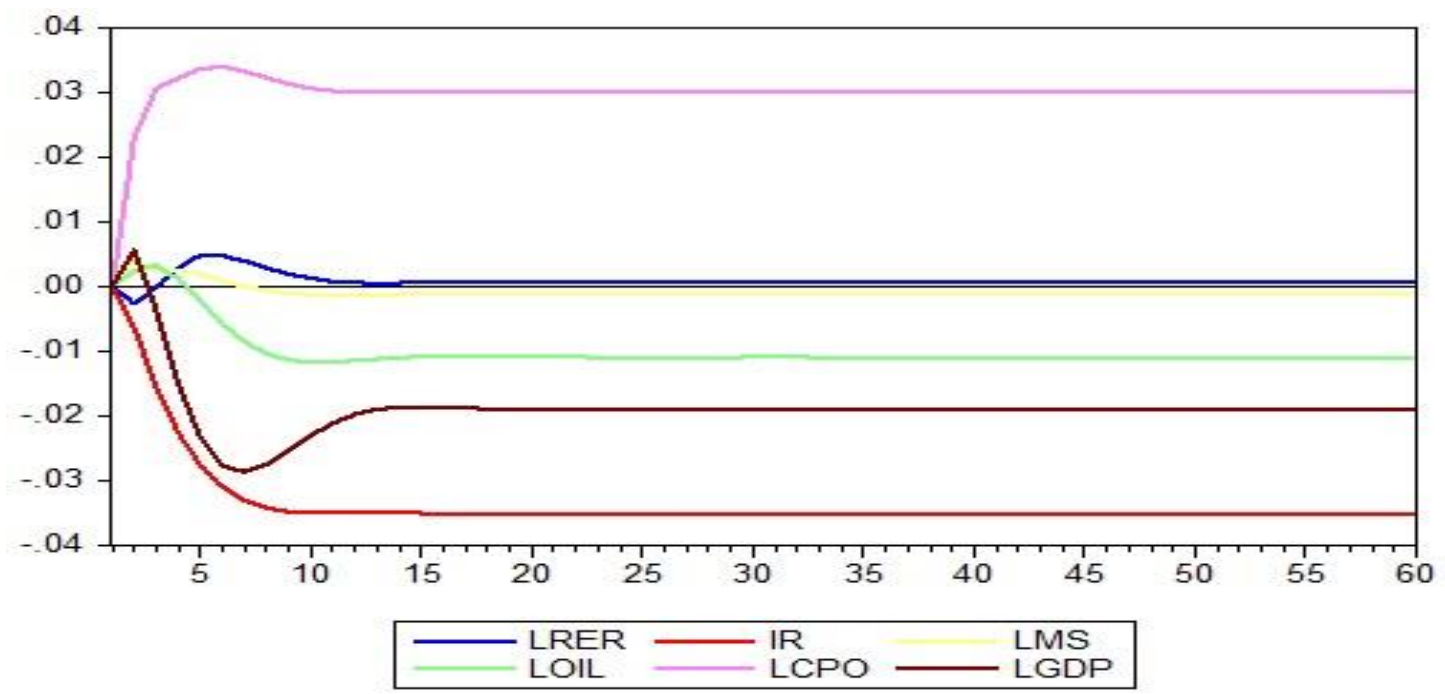

Gambar 2 Respon harga olein terhadap guncangan nilai tukar, suku bunga, jumlah uang beredar,harga minyak dunia, harga CPO dunia, dan GDP Indonesia

Apabila tejadi guncangan pada harga minyak dunia maka akan direspon positif oleh harga olein mulai periode kedua sampai periode keempat. Menurut Hartoyo et al. (2011), kenaikan harga minyak mentah dunia menyebabkan harga riil ekspor CPO Indonesia meningkat. Kenaikan harga riil ekspor CPO ini disebabkan oleh meningkatnya jumlah CPO yang digunakan untuk menghasilkan biodiesel sebagai komoditi substitusi minyak mentah. Selain itu menyebabkan terjadinya kenaikan produksi CPO, penurunan permintaan CPO untuk industri minyak goreng, dan penurunan produksi minyak goreng. Berdasarkan teori penawaran, apabila penawaran berkurang maka harga akan naik. Guncangan pada harga minyak dunia akan secara cepat ditransmisikan oleh harga olein sehingga mulai pada bulan kelima, peningkatan harga minyak dunia justru akan menurunkan harga olein. Hasil ini didukung oleh penelitian Arshad dan Hameed (2012), dimana harga minyak pada periode sebelumnya berhubungan negatif dengan harga CPO Malaysia. Guncangan harga minyak dunia akan stabil mulai periode ke 34 .

Olein merupakan produk turunan dari CPO sehingga harga CPO dunia mempunyai peran penting dalam pembentukan harga olein domestik. Apabila harga CPO dunia meningkat maka harga olein akan mengalami peningkatan. Guncangan harga CPO dunia pada bulan kedua direspon positif oleh harga olein sebesar 2,31 persen dan akan stabil pada periode ke 31 .

Jika terjadi guncangan GDP maka akan direspon positif harga olein pada periode kedua. Adanya peningkatan GDP sebagai proxy pendapatan maka akan meningkatkan permintaan olein. Akibatnya harga olein akan meningkat. Hasil ini didukung oleh Frankel dan Rose (2010). Mulai periode ketiga dan seterusnya, peningkatan GDP akan menurunkan harga olein. Asumsi peningkatan GDP karena peningkatan investasi. Adanya peningkatan investasi pada komoditi olein seperti peningkatan teknologi akan meningkatkan produksi olein. Dampak dari peningkatan produksi olein maka supply olein bertambah dan harga olein akan turun. Guncangan GDP akan stabil pada periode ke 40 .

Untuk melihat seberapa besar pengaruh random shock diantara variabel dalam model VECM digunakan analisis FEVD. FEVD mencirikan struktur dinamis antar variabel dalam model VAR/VECM. 
Dengan metode ini dapat dilihat kekuatan dan kelemahan dari masing-masing variabel dalam mempengaruhi variabel lainnya dalam kurun waktu yang panjang.
Pola dari FEVD mengindikasikan sifat dari kausalitas multivariate diantara variabel-variabel dalam model VAR.

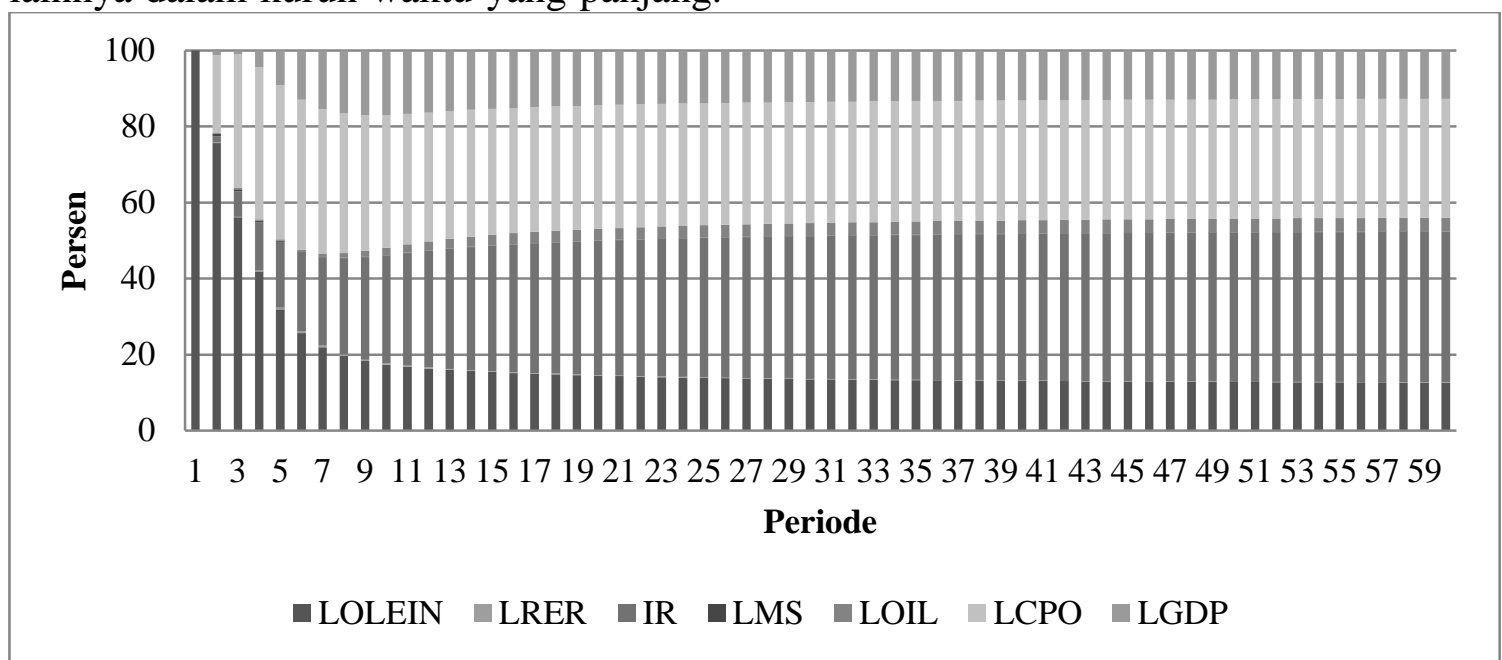

Gambar 3 Hasil FEVD faktor yang mempengaruhi harga olein

Variabilitas harga olein secara dominan dipengaruhi oleh harga olein itu sendiri sebesar 100 persen. Kemampuan harga olein mempengaruhi dirinya sendiri pada periode selanjutnya terus mengalami penurunan hingga pada periode ke 60 sebesar 12,66 persen.

Pengaruh nilai tukar rupiah terhadap dollar pada satu bulan sebelumnya kecil terhadap harga olein namun persentase nilai tukar rupiah terhadap dollar berangsur naik dari 0 persen pada periode pertama hingga 0.07 persen pada periode ke 60. Begitu juga pengaruh suku bunga pada bulan pertama sebesar 0 persen dan terus mengalami peningkatan sampai 39,59 persen pada bulan ke 60 .

Pada bulan pertama, pengaruh jumlah uang beredar sebesar 0 persen. Kemudian pengaruh ini meningkat sampai pada periode ke 60 sebesar 0,06 persen. Pengaruh harga minyak dunia sebesar 0 persen terhadap harga olein pada bulan pertama. Kemudian pengaruh ini meningkat sampai pada periode ke 60 sebesar 3,69 persen. Harga CPO dunia pada bulan pertama tidak mempengaruhi harga olein dan pengaruh itu mulai terlihat sejak periode kedua kemudian terus meningkat sampai pada periode ke 60 sebesar 31,20 persen. Sama hal nya dengan variabel lain, GDP belum mempengaruhi harga olein pada periode pertama tetapi sejak periode kedua, variabel ini mempengaruhi harga olein dan terus meningkat sampai dengan periode ke 60 sebesar 12,74 persen. Dengan kata lain, variabel yang berkontribusi besar pada awal periode adalah harga olein itu sendiri tetapi setelah periode ke 60 variabel yang mempunyai pengaruh terbesar terhadap harga olein adalah suku bunga. Artinya masyarakat Indonesia sudah dapat mengalokasikan pendapatannya antara konsumsi dan investasi. Apabila suku bunga acuan meningkat maka ada kecenderungan suku bunga tabungan dan deposito meningkat sehingga masyarakat lebih memilih mengalokasikan dana yang diterimanya dalam bentuk investasi tabungan atau deposito dan mengurangi konsumsi. Selanjutnya variabel yang berkontribusi paling kecil terhadap pembentukan harga olein pada periode ke 60 adalah jumlah uang beredar. Hasil ini sesuai dengan penelitian Awokuse (2005). 


\section{Analisis Integrasi Harga Olein}

Perubahan harga komoditi pada satu pasar dapat mengakibatkan perubahan harga pada pasar lainnya. Pada bagian ini, akan dibahas mengenai model yang dapat menjelaskan tentang integrasi harga komoditi olein antara pasar fisik Indonesia yang diwakili dengan harga olein Jakarta, pasar futures Indonesia yang diwakili dengan harga OLEINTR di BKDI, pasar acuan dunia yang diwakili dengan harga olein di Rotterdam. Metode yang akan digunakan untuk menjelaskan integrasi harga adalah metode VECM.

Tabel 6 Hasil pengujian akar unit tingkat level dan first difference integrasi harga olein

\begin{tabular}{lcccc}
\multirow{2}{*}{ Variabel } & \multicolumn{2}{c}{ Level } & \multicolumn{2}{c}{ First Difference } \\
\cline { 2 - 5 } & Adj t-Stat & Probabilitas & Adj t-Stat & Probabilitas \\
\hline LOLEINFISIK & $-1,59$ & 0,48 & $-4,12$ & $0,0028^{*}$ \\
LOLEINFUTURES & $-1,68$ & 0,43 & $-5,30$ & $0,0001^{*}$ \\
LOLEINACUAN & $-0,73$ & 0,82 & $-5,02$ & $0,0002^{*}$ \\
LRER & $-1,31$ & 0,61 & $-6,34$ & $0,0000^{*}$ \\
\hline
\end{tabular}

Keterangan : * stasioner pada taraf nyata $5 \%$

Tahap pertama dari pra estimasi VECM adalah uji akar unit. Uji akar unit yang dilakukan pada analisis ini adalah uji akar unit dengan PP Test. Untuk melihat kestasioneran data dapat dilihat dari nilai mutlak adjusted $\mathrm{t}$-statistik dan probabilitas. Jika nilai mutlak adjusted t-statistik lebih besar daripada critical values atau nilai probabilitas kurang dari taraf nyata yang digunakan maka data tersebut stasioner. Berdasarkan Tabel 6, semua variabel sudah stasioner pada first difference.

Selanjutnya dilakukan uji stabilitas VAR dengan menghitung akar-akar dari fungsi polinomial atau dikenal dengan roots of characteristic polinomial. Berdasarkan uji stabilitas yang dilakukan, model stabil pada lag 6 karena nilai roots of characteristic polinomial kurang dari 1 .

Uji ketiga yang dilakukan adalah uji optimum lag. Uji ini penting untuk menghilangkan masalah autokorelasi dalam sistem VAR. Penelitian ini menggunakan nilai SIC untuk menentukan lag optimal dan lag optimal yang dipilih adalah lag yang paling kecil yaitu lag 1 .

Sebelum melakukan estimasi VECM, dilakukan uji kointegrasi untuk mengetahui apakah akan terjadi keseimbangan jangka panjang. Asumsi yang akan dipilih adalah asumsi berdasarkan SIC yaitu asumsi kedua (intercept (no trend) in $\mathrm{CE}$ - no intercept in VAR untuk no deterministic trend). Kemudian dilanjutkan dengan penentuan jumlah kointegrasi. Ada dua kriteria yang dapat digunakan yaitu berdasarkan pada Trace Test atau Maximum eigen-value. Dalam penelitian ini menggunakan kriteria Trace Test. Hasil pengujian kointegrasi dapat dilihat pada Tabel 7.

Tabel 7 Hasil pengujian kointegrasi integrasi harga olein

\begin{tabular}{ccrrl}
\hline Hipotesis Nol & Hipotesis Alternatif & $\begin{array}{c}\text { Trace } \\
\text { Statistic }\end{array}$ & $\begin{array}{c}\text { Critical } \\
\text { Value }\end{array}$ & Probabilitas \\
\hline $\mathrm{r}=0$ & $\mathrm{r} \leq 1$ & 46,79 & 35,19 & $0,02^{*}$ \\
$\mathrm{r}=1$ & $\mathrm{r} \leq 2$ & 20,01 & 20,26 & 0,05 \\
$\mathrm{r}=2$ & $\mathrm{r} \leq 3$ & 6,26 & 9,16 & 0,17 \\
\hline
\end{tabular}

Keterangan : * signifikan pada taraf nyata 5\%

Berdasarkan Tabel 7 dapat dilihat bahwa terdapat satu kointegrasi yang ditunjukkan dengan nilai Trace statistic pada $r=0$ lebih besar dari critical value 
pada taraf nyata 5 persen. Ada kointegrasi diantara harga di pasar fisik Indonesia, harga di pasar futures BKDI dan harga di pasar acuan dapat menunjukkan adanya integrasi pasar yaitu antara pasar fisik Indonesia, pasar futures Indonesia dan pasar acuan dunia. Hal ini didukung dengan Fackler dan Goodwin (2001) yang menyatakan bahwa jika ada dua pasar yang terpisah series harga nya terkointegrasi maka ada kecenderungan terjadi pergerakan yang sama pada jangka panjang diantara keduanya berdasarkan hubungan linier.
Berdasarkan analisis pra estimasi yang telah dilakukan, harga di pasar fisik Indonesia, harga futures di BKDI dan harga acuan di Rotterdam terkointegrasi sehingga analisis selanjutnya yang dilakukan adalah estimasi VECM. Hubungan keseimbangan dinamis jangka pendek dan keseimbangan jangka panjang dalam satu sistem persamaan dapat digambarkan oleh model ini. Selain itu, model VECM ini dapat menunjukkan kombinasi hubungan jangka pendek dan jangka panjang antar harga-harga dari pasar yang berbeda (Anwar, 2005).

Tabel 8 Hasil estimasi VECM jangka panjang integrasi harga olein

\begin{tabular}{lcc}
\hline \multicolumn{1}{c}{ Variabel } & Koefisien & t-Statistik \\
\hline LOLEINFUTURES(-1) & $-3,54$ & $-6,24^{*}$ \\
LOLEINACUAN(-1) & 1,41 & $3,83^{*}$ \\
\hline
\end{tabular}

Keterangan : * signifikan pada taraf nyata $5 \%$

Pada jangka panjang, perubahan harga olein di pasar fisik Indonesia dipengaruhi oleh perubahan harga olein di pasar futures Indonesia dan pasar acuan dunia di Rotterdam. Adanya pengaruh jangka panjang harga fisik dan harga futures didukung oleh penelitian Silvapulle dan Moosa (1999) terhadap harga minyak mentah WTI. Sedangkan hubungan pasar fisik dan pasar acuan didukung oleh penelitian Hafizah (2009) terkait komoditi CPO, dimana pasar forward Rotterdam merupakan pasar referensi atau pasar acuan bagi pasar fisik Indonesia.

Pada Tabel 8 menunjukkan bahwa peubah persamaan kointegrasi 1 signifikan terhadap harga olein Indonesia. Keseimbangan jangka pendek akan menyesuaikan menuju keseimbangan jangka panjang. Nilai ECT sebesar -0,09 dan signifikan pada taraf nyata 5 persen, artinya proses penyesuaian terjadi menuju keseimbangan jangka panjang dengan kecepatan sebesar -0,09 persen per bulan.

Tabel 9 Hasil estimasi VECM jangka pendek integrasi harga olein

\begin{tabular}{lccc}
\hline \multirow{2}{*}{$\begin{array}{c}\text { Error } \\
\text { Correction }\end{array}$} & \multicolumn{3}{c}{ Koefisien dan t-Statistik } \\
\cline { 2 - 4 } & D(LOLEIN & D(LOLEIN & D(LOLEIN \\
& FISIK) & FUTURES) & ACUAN) \\
\hline CointEq1 & $-0,09 *$ & 0,10 & $-0,01$ \\
& {$[-3,26]$} & {$[1,46]$} & {$[-0,14]$} \\
D(LOLEINFISIK(-1)) & $-0,13$ & $-0,26$ & $-0,19$ \\
& {$[-0,71]$} & {$[-0,62]$} & {$[-0,44]$} \\
D(LOLEINFUTURES(-1)) & $-0,10$ & 0,03 & 0,18 \\
& {$[-0,78]$} & {$[0,11]$} & {$[0,57]$} \\
D(LOLEINACUAN(-1)) & 0,182 & 0,29 & 0,09 \\
& {$[1,42]$} & {$[0,97]$} & {$[0,30]$} \\
\hline
\end{tabular}

Keterangan : * signifikan pada taraf nyata $5 \%$ 
Secara statistik, perubahan harga olein di pasar acuan Rotterdam dalam jangka pendek tidak mempengaruhi perubahan harga fisik dan harga futures olein di Indonesia. Hal ini menunjukkan bahwa kondisi pasar olein Indonesia baik pasar fisik maupun pasar futures tidak terintegrasi dengan pasar acuan Rotterdam. Adanya perubahan harga di pasar acuan Rotterdam tidak langsung ditransmisikan terhadap harga olein di dalam negeri. Kondisi pasar yang tidak terintegrasi menunjukkan bahwa pasar belum bekerja secara efisien dan efektif.

Negara-negara di Eropa merupakan negara yang mengkonsumsi minyak rappa terbesar (Carre dan Puuzet, 2014). Hal ini menunjukkan bahwa kondisi pasar Eropa berbeda karakter dengan pasar Indonesia dimana olein bukan merupakan minyak nabati utama yang dikonsumsi melainkan minyak rappa. Akibatnya perubahan harga olein di pasar Rotterdam tidak langsung ditransmisikan ke pasar Indonesia. Selain itu, komoditi olein merupakan salah satu komoditi yang dijaga kestabilan harganya oleh pemerintah sehingga pergerakan harga di pasar acuan tidak langsung mempengaruhi harga di pasar Indonesia.

Setelah mengetahui bahwa pasar dalam negeri terintegrasi dengan pasar acuan dunia dalam jangka panjang, selanjutnya dilakukan suatu simulasi guncangan harga. Dalam penelitian ini jangka waktu proyeksi yang digunakan dalam menganalisis respon adalah selama 60 bulan (5 tahun) ke depan dan akan dicoba untuk dilihat bagaimana respon harga di pasar fisik dan pasar futures Indonesia terhadap guncangan harga di pasar acuan dunia. Respon guncangan harga di pasar acuan terhadap harga di pasar fisik dan futures Indonesia dapat dilihat pada Gambar 4 dan 5.

Berdasarkan Gambar 4, respon harga fisik olein terhadap perubahan harga olein di pasar acuan Rotterdam pada bulan pertama belum terjadi. Respon guncangan yang terjadi di pasar acuan Rotterdam akan berpengaruh mulai bulan kedua sebesar 0,11 persen. Apabila harga olein di pasar Rotterdam meningkat satu persen maka harga olein di Indonesia akan meningkat sebesar 0,11 persen. Persamaan pergerakan respon ini didukung oleh penelitian Hafizah (2009) dimana adanya guncangan pada pasar CPO di Rotterdam sebesar satu persen mengakibatkan harga CPO di pasar fisik Indonesia meningkat sebesar 3,6 persen.

Pada bulan ketiga, apabila di pasar Rotterdam mengalami peningkatan satu persen justru mengakibatkan harga olein di Indonesia mengalami penurunan sebesar 0,03 persen. Respon yang sama juga terlihat pada harga CPO di Malaysia dalam penelitian Hafizah (2009). Ketika harga CPO di Rotterdam mengalami guncangan sebesar satu persen maka harga CPO di pasar fisik Malaysia mengalami penurunan sebesar 0,9 persen pada bulan kedua dan ketiga. 


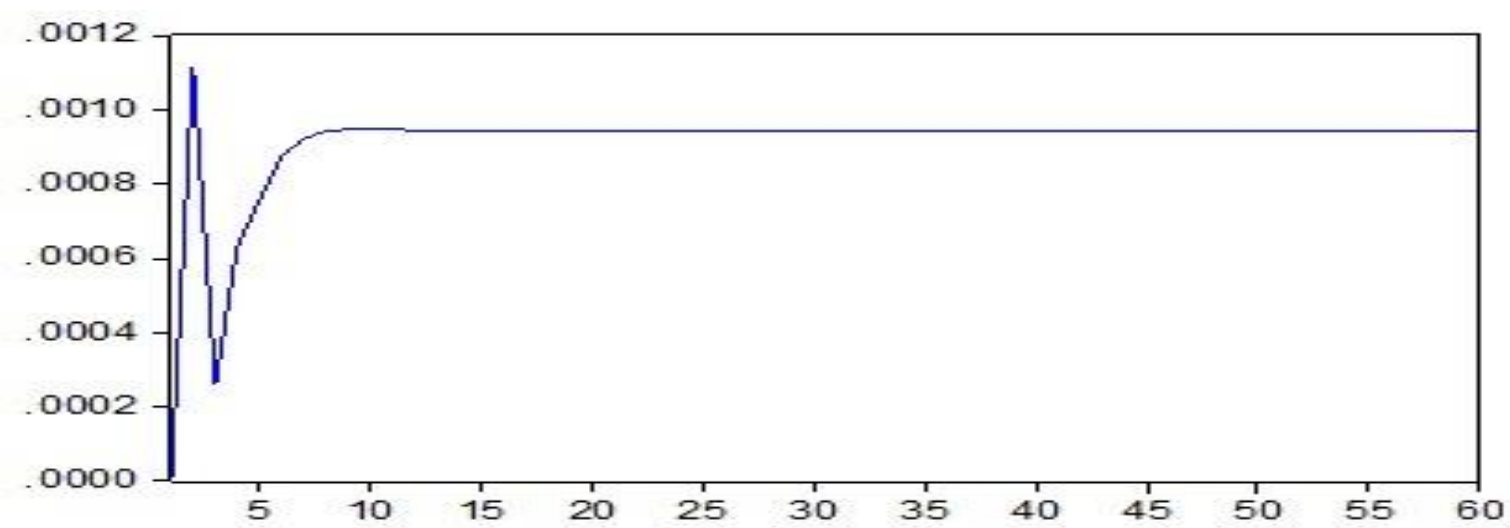

Gambar 4 Respon guncangan harga di pasar acuan terhadap pasar fisik Indonesia

Mulai bulan keempat dan pasar Rotterdam akan stabil mulai bulan ke seterusnya, peningkatan harga olein di 14 pada tingkat 0,09 persen. pasar Rotterdam akan meningkatkan harga Seperti hal nya pasar fisik di olein di pasar Indonesia. Hal ini sesuai Indonesia, pasar futures Indonesia belum penelitian yang dilakukan Hafizah (2009) merespon guncangan yang terjadi di pasar terhadap komoditi CPO dimana pasar acuan pada awal bulan. Pada bulan kedua acuan Rotterdam merupakan pasar respon positif diberikan atas kejutan harga referensi bagi pasar Indonesia. Setiap perubahan yang terjadi di pasar Rotterdam akan mengakibatkan perubahan pada pasar CPO Indonesia. Guncangan yang terjadi di acuan dan mencapai keseimbangan jangka panjang pada bulan ke 14 pada tingkat 0,99 persen.

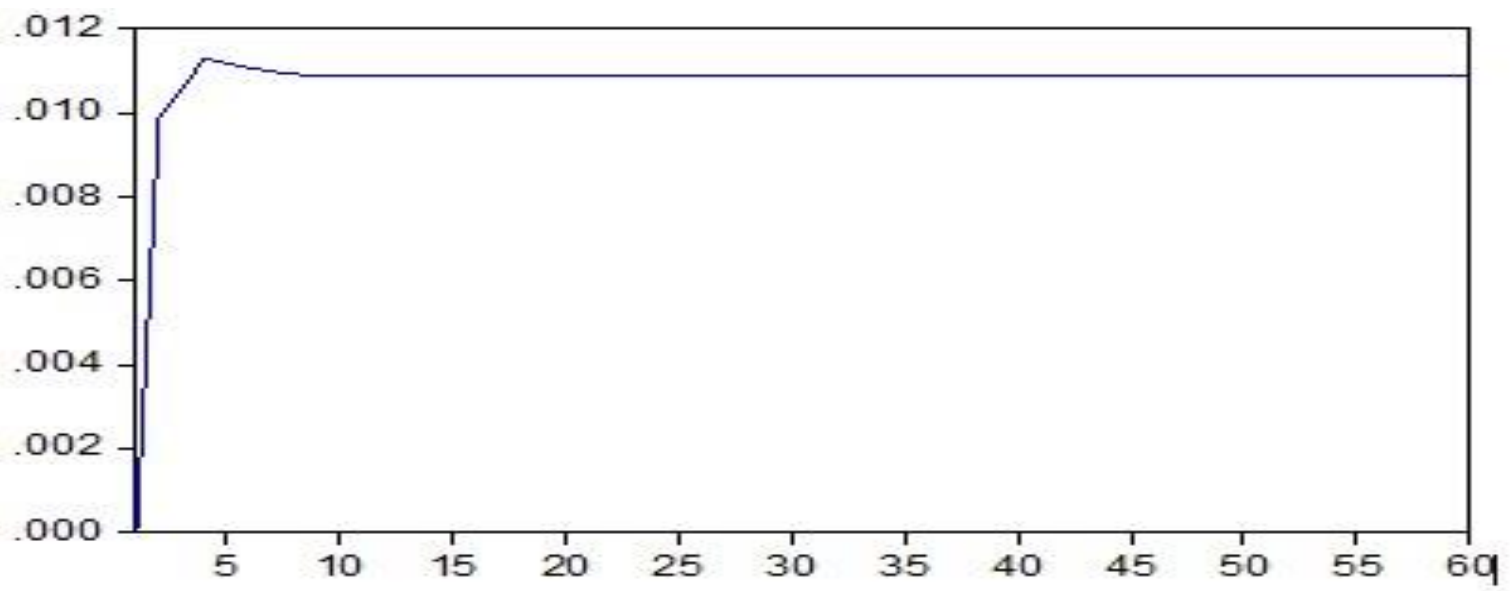

Gambar 5 Respon guncangan harga di pasar acuan terhadap pasar futures Indonesia

Tahap selanjutnya adalah analisis FEVD. Analisis ini berfungsi untuk menjelaskan kontribusi masing-masing variabel shock atau guncangan yang ditimbulkannya terhadap variabel utama endogen yang diamati. FEVD mampu menjelaskan proporsi variabel lain dalam menjelaskan variabel endogen utama penelitian.
Variasi harga olein saat ini dapat dijelaskan oleh harga sendiri sebesar 100 persen dan menurun pada tingkat 39,37 persen saat 60 bulan kemudian. Pada periode ke 60 , variasi harga olein di pasar fisik Indonesia juga dipengaruhi oleh harga olein di pasar futures sebesar 60,56 persen dan harga olein di pasar acuan sebesar 0,07 persen. 


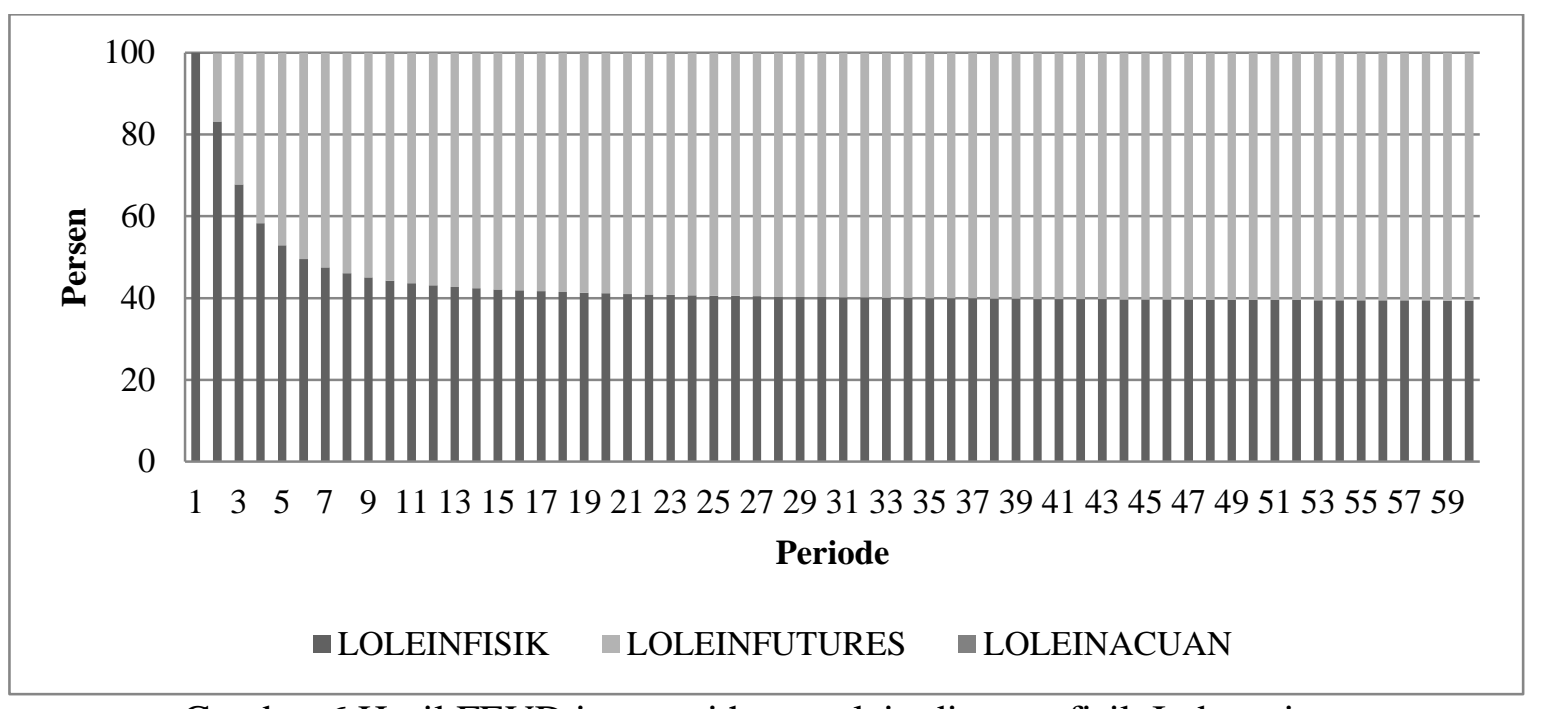

Gambar 6 Hasil FEVD integrasi harga olein di pasar fisik Indonesia

Variasi harga olein di pasar futures Indonesia pada posisi saat ini dijelaskan oleh harga futures olein sebesar 88,61 persen dan harga fisik olein sebesar 11,39 persen. Sedangkan pada periode ke 60 kemudian, variasi harga olein di pasar futures Indonesia dijelaskan oleh harga futures itu sendiri sebesar 79,77 persen, harga fisik sebesar 9,46 persen, dan harga acuan sebesar 10,77 persen. Berdasarkan Gambar 6 dan 7, dapat disimpulkan bahwa harga acuan olein di pasar Rotterdam kurang memberikan pengaruh terhadap pembentukan harga di pasar fisik maupun di pasar futures Indonesia.

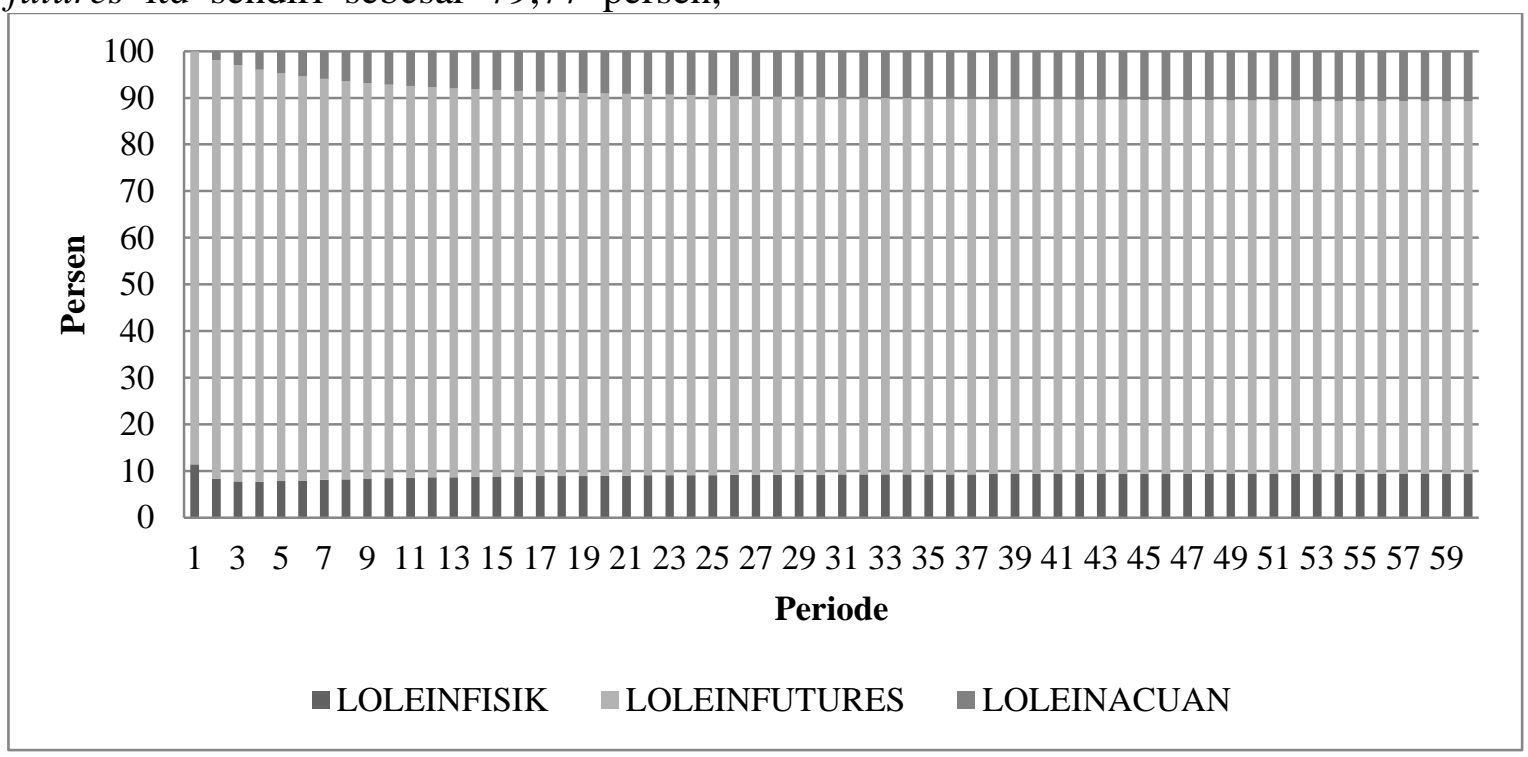

Gambar 7 Hasil FEVD integrasi harga olein di pasar futures Indonesia

Menurut Aji (2010), secara historis kawasan Eropa terutama Belanda merupakan konsumen CPO Indonesia sejak jaman penjajahan Belanda. Oleh karena itu, wajar apabila harga CPO
Indonesia masih mengacu ke harga $\mathrm{CPO}$ Rotterdam. Hasil penelitian ini menunjukkan bahwa harga komoditi olein di Rotterdam justru kurang memberikan pengaruh terhadap pembentukan harga 
olein dalam negeri. Sehingga dapat disimpulkan bahwa harga olein di pasar fisik dan pasar futures tidak mengacu pada harga Rotterdam. Masih terdapat faktor lain diluar harga acuan yang menentukan harga olein di pasar fisik dan pasar futures Indonesia.

Rifin (2009) menyatakan bahwa India dan Tiongkok merupakan pasar yang relatif baru bagi minyak kelapa sawit Indonesia dibandingkan pasar Belanda yang sudah ada sejak tahun 1960-an. Bukanlah suatu hal yang mudah untuk menjadikan harga CPO Indonesia sebagai harga referensi karena sulitnya mengalihkan pihak swasta yang telah menjadikan harga CPO Rotterdam sebagai harga referensi. Hal yang sama juga berlaku bagi komoditi olein.

\section{KESIMPULAN DAN SARAN KESIMPULAN}

Adapun kesimpulan yang dapat diambil dari penelitian ini, antara lain:

1. Dari hasil analisis VECM, terdapat keseimbangan antara jangka pendek dan jangka panjang. Dalam jangka pendek, harga olein dipengaruhi oleh harga minyak dunia, harga $\mathrm{CPO}$ dunia, dan GDP Indonesia. Sedangkan dalam jangka panjang, harga olein dipengaruhi oleh nilai tukar, suku bunga, jumlah uang beredar, harga CPO dunia, dan GDP Indonesia. Apabila suku bunga mengalami guncangan maka akan direspon negatif oleh harga olein. Sedangkan apabila harga CPO dunia mengalami guncangan akan direspon positif oleh harga olein. Berdasarkan analisis FEVD, variasi harga olein pada periode pertama secara dominan dipengaruhi oleh harga olein itu sendiri. Pada periode ke 60, variasi harga olein dipengaruhi oleh suku bunga, harga CPO dunia, GDP Indonesia, harga olein, harga minyak dunia, nilai tukar, dan jumlah uang beredar.

2. Berdasarkan analisis VECM yang digunakan, terjadi integrasi antara harga fisik, harga futures dan harga acuan dunia dalam jangka panjang. Sedangkan dalam jangka pendek tidak terjadi integrasi harga sehingga apabila ada perubahan harga di salah satu pasar tidak langsung ditransmisikan terhadap harga di pasar lainnya. Hal ini menunjukkan bahwa pasar komoditi olein Indonesia belum bekerja secara efisien dan efektif.

\section{SARAN}

Beberapa saran yang dapat diajukan, antara lain:

1. Adanya respon yang berbeda yang dihasilkan harga olein terhadap guncangan faktor-faktor yang mempengaruhi membuat pelaku pasar perlu mengambil tindakan. Salah satu tindakan yang dapat dilakukan adalah mengamati dan meramalkan pergerakan variabel makroekonomi dan mikroekonomi. Selain itu, pelaku pasar olein dapat memanfaatkan bursa berjangka komoditi untuk lindung nilai. Dengan keikutsertaan pelaku pasar dalam bursa berjangka komoditi diharapkan dapat mengurangi resiko yang timbul akibat fluktuasi harga komoditi.

2. Kondisi pasar olein Indonesia tidak terintegrasi dengan pasar acuan dunia dalam jangka pendek. Hal ini mengakibatkan setiap perubahan yang terjadi di pasar dunia tidak langsung ditransmisikan terhadap harga olein di dalam negeri. Tidak terintegrasinya harga olein Indonesia mengindikasikan bahwa sistem yang berlangsung pada komoditi ini masih belum efisien dan efektif. Untuk itu perlu peran serta pemerintah dalam mengefisienkan sistem pemasaran komoditi ini. Salah satu nya dengan mengatur tata niaga 
olein. Sistem yang efisien dapat membantu proses pembentukan harga sehingga Indonesia sebagai negara produsen dapat menjadi price maker dan dijadikan referensi harga bagi pelaku pasar dalam dan luar negeri. Selain itu, perlu dilakukan kesepakatan antara Indonesia dan Malaysia sebagai negara produsen CPO agar membuat formulasi harga olein sehingga harga kesepakatan di kedua negara tersebut dapat dijadikan acuan bagi pelaku pasar olein di dunia.

3. Terkait dengan variabel yang digunakan, masih banyak variabel faktor yang mempengaruhi harga komoditi yang tidak digunakan seperti

\section{DAFTAR PUSTAKA}

Ahsan H, Iftikhar Z, Kemal MA. 2011. The Determinants of Food Prices: A Case Study of Pakistan. PIDE Working Papers. 76:1-21

Aji BWP. 2010. Analisis Integrasi Harga Minyak Bumi, Minyak Kedelai, CPO, Minyak Goreng Domestik dan Tandan Buah Segar Kelapa Sawit [tesis]. Bogor: Program Pascasarjana, Institut Pertanian Bogor.

Anwar C. 2005. Prospek Karet Alam Indonesia di Pasar Internasional: Suatu Analisis Integrasi Pasar dan Keragaan Ekspor [disertasi]. Bogor: Program Pascasarjana, Institut Pertanian Bogor.

Arango LE, Arias F, Florez A. 2012. Determinants of Commodity Prices. Applied Economics. 44(2): 135-145.

Arshad FM, Hameed AAA. 2012. Crude Oil, Palm Oil Stock and Prices: How They Link. Review of Economics and Finance. 48-57.

Awokuse TO. 2005. Impact of Macroeconomic Policis on Agricultural Prices. Agricultural and Resource Economic Review. 34(2): 226-237.

Balcombe K. 2010. The Nature and Determinants of Volatility in pendapatan per kapita, produksi, konsumsi, dan kebijakan yang terkait dengan komoditi. Sedangkan dalam analisis integrasi, penggunaan harga komoditi di beberapa kota besar di Indonesia serta harga futures dari berbagai bursa berjangka komoditi di luar negeri dapat memperkaya hasil sehingga akan lebih jelas terlihat bagaimana integrasi harga komoditi olein. Selanjutnya terkait komoditi yang digunakan, penelitian selanjutnya dapat menggunakan komoditi yang sudah dijadikan subjek kontrak berjangka komoditi di bursa berjangka komoditi seperti kakao, kopi, dan CPO.

Agricultural Prices: An Empirical Study From 1962-2008. Commodity Market Review 2009-2010. 1-24.

Bappebti [Badan Pengawas Perdagangan Berjangka Komoditi]. 2009-2014. Annual Report 2009-2014. Jakarta (ID): Kementerian Perdagangan.

Bastourre D, Carrera J, Ibarlucia J. 2010. Commodity Prices: Structural Factors, Financial Markets and Non-linear Dynamics. BCRA Paper Series. 6:15-23.

Carre P, Pouzet A. 2014. Rapeseed Market, Worldwide and in Europe. Oilseeds and fats Crops and Lipids Journal. 21(1): 1-12.

DCE [Dalian Commodity Exchange]. 2014. Volume Transaction of RBD Palm Olein.

Enders W. 2004. Applied Econometrics Time Series $2^{\text {nd }} E d$. Danvers (US): John Wiley and Sons.

Fackler PL, Goodwin BK. 2001. Spacial Price Analysis. North Carolina State (US): North Carolina State University.

Frankel JA. 2006. The Effect of Monetary Policy on Real Commodity Prices. NBER Working Paper Series. 12713: $1-40$. 
Frankel JA, Rose AK. 2010. Determinants of Agricultural and Mineral Commodity Prices. HKS Faculty Research Working Paper Series. RWP10-038: 1-48.

GAPKI. 2014. Industri Minyak Sawit Indonesia Menuju 100 Tahun NKRI. Jakarta (ID): PASPI.

Gujarati D. 2007. Dasar-dasar Ekonometrika. Mulyadi JA, penerjemah: Saat S dan Hardani, editor. Jakarta (ID): Erlangga. Terjemahan dari: Essentials of Econometrics.

Hafizah D. 2009. Integrasi Pasar Fisik CPO Di Indonesia, Malaysia Dan Pasar Berjangka Di Rotterdam [tesis]. Bogor: Program Pascasarjana, Institut Pertanian Bogor.

Harri A, Nalley L, Hudson D. 2009. The Relationship between Oil, Exchange Rate, and Commodity Prices. Journal of Agricultural and Applied Economics. 41(2): 501-510.

Hartoyo S, Putri EIK, Novindra, Hastuty. 2011. Dampak Kenaikan Harga Minyak Bumi Terhadap Ketersediaan Minyak Goreng Sawit Domestik. Jurnal Ekonomi dan Pembangunan Indonesia. 11(2): 169-179.

Helbling T, Blackman VM, Cheng K. 2008. Riding a Wave. Finance and Development. 3: 10-15.

Kementan [Kementerian Pertanian]. 2014. Laporan Luas Areal, Produksi dan Produktivitas Perkebunan di Indonesia.
Kementerian Pertanian. Jakarta [Laporan]

Nkang NM, Ndifon HM, Odok GN. 2007. Price Transmission and Integration of Cocoa and Palm Oil Markets in Cross River State, Nigeria: Implications for Rural Development. Agricultural Journal. 2(4): 457-463.

Nugraheni SRW. 2014. Volatilitas Harga Pangan Utama Indonesia dan Faktor yang Mempengaruhinya [tesis]. Bogor: Program Pascasarjana, Institut Pertanian Bogor.

PDN [Perdagangan Dalam Negeri]. 2014. Statistik Perdagangan Dalam Negeri Indonesia. Jakarta (ID): Kementerian Perdagangan.

Rachman A. 2012. Integrasi Dan Transmisi Harga Pada Pasar CPO Dan Minyak Goreng Sawit Di Indonesia [tesis]. Bogor: Program Pascasarjana, Institut Pertanian Bogor.

Rifin A. 2009. Analisis Pemasaran Minyak Kelapa Sawit di Indonesia dalam Bunga Rampai Agribisnis: Seri Pemasaran. Bogor (ID): IPB Press.

Silvapulle P, Moosa I. 1999. The Relationship between Spot and Futures Prices: Evidence from The Crude Oil Market. Journal of Futures Market. 19(2): 175-193.

World Bank. 2014. Population and GDP per Capita Indicators. 


\section{LAMPIRAN}

Lampiran 1 Uji stabilitas VAR faktor yang mempengaruhi harga olein

Roots of Characteristic Polynomial

Endogenous variables: LOLEIN LRER IR LMS LOIL

LCPO LGDP

Exogenous variables: C DUMMY

Lag specification: 16

\begin{tabular}{|c|c|}
\hline Root & Modulus \\
\hline 0.998645 & 0.998645 \\
\hline $0.851255+0.476073 i$ & 0.975336 \\
\hline $0.851255-0.476073 i$ & 0.975336 \\
\hline $0.947603-0.137482 i$ & 0.957525 \\
\hline $0.947603+0.137482 i$ & 0.957525 \\
\hline $0.466198+0.815291 i$ & 0.939170 \\
\hline $0.466198-0.815291 \mathrm{i}$ & 0.939170 \\
\hline$-0.496576+0.788934 i$ & 0.932204 \\
\hline$-0.496576-0.788934 \mathrm{i}$ & 0.932204 \\
\hline $0.876951-0.179174 i$ & 0.895068 \\
\hline $0.876951+0.179174 i$ & 0.895068 \\
\hline$-0.121387+0.872190 \mathrm{i}$ & 0.880597 \\
\hline$-0.121387-0.872190 \mathrm{i}$ & 0.880597 \\
\hline 0.859084 & 0.859084 \\
\hline $0.780169-0.358122 i$ & 0.858438 \\
\hline $0.780169+0.358122 i$ & 0.858438 \\
\hline $0.122508-0.845382 i$ & 0.854213 \\
\hline $0.122508+0.845382 i$ & 0.854213 \\
\hline $0.717748-0.456681 \mathrm{i}$ & 0.850717 \\
\hline $0.717748+0.456681 i$ & 0.850717 \\
\hline$-0.807443-0.188770 \mathrm{i}$ & 0.829215 \\
\hline$-0.807443+0.188770 i$ & 0.829215 \\
\hline$-0.290618+0.753163 i$ & 0.807287 \\
\hline$-0.290618-0.753163 i$ & 0.807287 \\
\hline$-0.708830+0.358932 i$ & 0.794526 \\
\hline$-0.708830-0.358932 i$ & 0.794526 \\
\hline$-0.783969+0.094530 i$ & 0.789648 \\
\hline$-0.783969-0.094530 i$ & 0.789648 \\
\hline $0.427557-0.614054 i$ & 0.748243 \\
\hline $0.427557+0.614054 i$ & 0.748243 \\
\hline $0.242046+0.677925 i$ & 0.719839 \\
\hline $0.242046-0.677925 i$ & 0.719839 \\
\hline $0.682145-0.195589 i$ & 0.709632 \\
\hline $0.682145+0.195589 i$ & 0.709632 \\
\hline$-0.353077+0.530516 i$ & 0.637268 \\
\hline$-0.353077-0.530516 i$ & 0.637268 \\
\hline$-0.479277-0.374332 i$ & 0.608137 \\
\hline$-0.479277+0.374332 i$ & 0.608137 \\
\hline $0.071424+0.508297 i$ & 0.513291 \\
\hline $0.071424-0.508297 i$ & 0.513291 \\
\hline 0.441183 & 0.441183 \\
\hline-0.137243 & 0.137243 \\
\hline
\end{tabular}

No root lies outside the unit circle.

VAR satisfies the stability condition. 
Lampiran 2 Uji optimum lag faktor yang mempengaruhi harga olein

VAR Lag Order Selection Criteria

Endogenous variables: LOLEIN LRER IR LMS LOIL LCPO LGDP

Exogenous variables: C DUMMY

Sample: 2005M07 2014M12

Included observations: 108

\begin{tabular}{ccccccc}
\hline \hline Lag & LogL & LR & FPE & AIC & SC & HQ \\
\hline \hline 0 & 527.4123 & NA & $1.75 \mathrm{e}-13$ & -9.507635 & -9.159951 & -9.366662 \\
1 & 1459.055 & 1708.012 & $1.40 \mathrm{e}-20$ & -25.85287 & $-24.28830^{*}$ & -25.21850 \\
2 & 1553.954 & 161.6801 & $6.06 \mathrm{e}-21$ & -26.70286 & -23.92139 & $-25.57507^{*}$ \\
3 & 1621.852 & 106.8761 & $4.40 \mathrm{e}-21^{*}$ & -27.05282 & -23.05446 & -25.43163 \\
4 & 1664.037 & 60.93354 & $5.30 \mathrm{e}-21$ & -26.92661 & -21.71135 & -24.81201 \\
5 & 1707.984 & 57.78166 & $6.41 \mathrm{e}-21$ & -26.83303 & -20.40088 & -24.22503 \\
6 & 1776.653 & $81.38636^{*}$ & $5.17 \mathrm{e}-21$ & $-27.19728^{*}$ & -19.54824 & -24.09587 \\
\hline \hline
\end{tabular}

* indicates lag order selected by the criterion

LR: sequential modified LR test statistic (each test at $5 \%$ level)

FPE: Final prediction error

AIC: Akaike information criterion

SC: Schwarz information criterion

$\mathrm{HQ}$ : Hannan-Quinn information criterion

Lampiran 3 Uji stabilitas VAR integrasi harga olein

Roots of Characteristic Polynomial

Endogenous variables: LOILEINFISIK LOLEINFUTURES

LOLEINACUAN

Exogenous variables: C LRER

Lag specification: 16

\begin{tabular}{cc}
\hline \hline Root & Modulus \\
\hline \hline $0.909271-0.238243 i$ & 0.939965 \\
$0.909271+0.238243 i$ & 0.939965 \\
$0.608197-0.701235 i$ & 0.928243 \\
$0.608197+0.701235 i$ & 0.928243 \\
0.875231 & 0.875231 \\
$-0.311146-0.778863 i$ & 0.838713 \\
$-0.311146+0.778863 i$ & 0.838713 \\
-0.833436 & 0.833436 \\
$-0.484351+0.676161 i$ & 0.831738 \\
$-0.484351-0.676161 i$ & 0.831738 \\
$0.106458+0.805597 i$ & 0.812601 \\
$0.106458-0.805597 i$ & 0.812601 \\
$0.405413+0.667252 i$ & 0.780759 \\
$0.405413-0.667252 i$ & 0.780759 \\
$-0.579218+0.194320 i$ & 0.610945 \\
$-0.579218-0.194320 i$ & 0.610945 \\
0.416497 & 0.416497 \\
-0.003472 & 0.003472 \\
\hline \hline
\end{tabular}

No root lies outside the unit circle.

VAR satisfies the stability condition. 
Lampiran 4 Uji optimum lag integrasi harga olein

VAR Lag Order Selection Criteria

Endogenous variables: LOILEINFISIK LOLEINFUTURES LOLEINACUAN

Exogenous variables: C LRER

Sample: $2011 \mathrm{M} 12$ 2014M12

Included observations: 31

\begin{tabular}{ccccccc}
\hline \hline Lag & LogL & LR & FPE & AIC & SC & HQ \\
\hline \hline 0 & 135.9116 & NA & $4.60 \mathrm{e}-08$ & -8.381396 & -8.103850 & -8.290923 \\
1 & 216.6264 & $135.3925^{*}$ & $4.54 \mathrm{e}-10^{*}$ & $-13.00816^{*}$ & $-12.31429^{*}$ & $-12.78197^{*}$ \\
2 & 219.7438 & 4.625860 & $6.82 \mathrm{e}-10$ & -12.62864 & -11.51845 & -12.26674 \\
3 & 231.7647 & 15.51078 & $5.96 \mathrm{e}-10$ & -12.82353 & -11.29703 & -12.32593 \\
4 & 238.4055 & 7.283499 & $7.78 \mathrm{e}-10$ & -12.67133 & -10.72850 & -12.03801 \\
5 & 245.9544 & 6.818338 & $1.04 \mathrm{e}-09$ & -12.57770 & -10.21856 & -11.80868 \\
6 & 252.8716 & 4.908996 & $1.64 \mathrm{e}-09$ & -12.44333 & -9.667872 & -11.53860 \\
\hline \hline
\end{tabular}

* indicates lag order selected by the criterion

LR: sequential modified LR test statistic (each test at $5 \%$ level)

FPE: Final prediction error

AIC: Akaike information criterion

SC: Schwarz information criterion

$H Q$ : Hannan-Quinn information criterion 